\title{
Value added distribution in Russian corporations: case of Gazprom
}

\author{
Dmitri Pletnev ${ }^{1 *}$ \\ ${ }^{1}$ Chelyabinsk State University, 129, Br. Kashirinykh st., Chelyabinsk, 454001, Russia
}

\begin{abstract}
The modern Russian economy is basically the economy of corporations, both public and private. For this reason, the peculiarities of economic relations between the main centers of power in corporations and outside them, affect the results and efficiency of the economy. Corporations are becoming instruments of geopolitical influence, establishing economic ties with neighboring countries even under conditions of external pressure. One of the typical Russian corporations today is Gazprom, the largest gas producer. It combines the strengths of both the state and private corporations. The article considers in detail the distribution of value added to Gazprom according to the consolidated financial statements for 2012-2017. It reveals trends and patterns that allow to determine the strengths and weaknesses of this corporation as a driver of the development of the Russian economy. The main stakeholders (state, employees, top management and creditors) are identified. The research uses methods of synthesizing the partial indicators of various forms of reporting, data from Gazprom's official website and open sources. The uniqueness of the research consists in the author's method of calculating the amounts of value added received by each stakeholder. The role of the State as the main stakeholder of the corporation Gazprom is justified.
\end{abstract}

\section{Introduction}

Starting with the economic tables by Quesnay, further in the works by A. Smith, D. Ricardo and K. Marx, the concept of increasing value as the product progressed in the production chain was gradually defined. The trends of the social division of labor and production specialization that have emerged at that time, have formed today a portrait of a modern economy in which production processes are often international in nature. Enterprises as a "thing-in-itself", engaged in local production and local sales of their products are less and less common today. The activity of the companies involves the masses of employees, their families, owners of various securities and indirectly - a significant part of the population that has deposits in bank. In addition, consumers of externalities are the residents of the territories where enterprises operate. The recipients of budgetary funds - the system of national defense, education and healthcare - depend on the work of enterprises through the fiscal system. Thanks to the taxes paid by the company or arising from the company's work, many public benefits are produced. All these effects of distribution of the result created by

*Corresponding author: pletnev@csu.ru 
the company are described in terms of the value created and distributed to it. Most often economists speak of the value added, although adherents of the classical and Marxist schools use the notion of the "surplus value". The difference in these terms is in the only item - the amount of employees' income (it is included in the value added, but in the surplus value - it is not, for this reason the notion of the "surplus value" has an ideological connotation). The way the largest corporations distribute the value added created in the process of their activity is a very important economic problem.

The purpose of the article is to analyze the distribution of the value added of PJSC Gazprom, the largest producer and supplier of natural gas in Russia, one of the leaders in capitalization on the Russian stock market. The modern Russian economy is basically the economy of corporations, both public and private. For this reason, the peculiarities of economic relations between the main centers of power in corporations and outside them, affect the results and efficiency of the economy. Corporations are becoming instruments of geopolitical influence, establishing economic ties with neighboring countries even under conditions of external pressure. One of the typical Russian corporations today is Gazprom, the largest gas producer. It combines the strengths of both the state and private corporations. At the same time, it is not free from the limitations inherent in them.

\section{Literature Review}

Modern studies of problems of the value added distribution are mostly of an applied nature: the process of creating value added in American agriculture and related industries in the second half of the 20th century is considered in detail in the work by Coltrain, Barton, and Boland [1]. The authors define the value added as the process of changing or transforming a product from its original state to a more valuable state. Consequently, the value added is distributed in accordance with the process of its addition. It is possible if all participants of the value added chain are independent market agents and build their relations based on the explicit contracts. In their estimation, the value added in the sector under investigation tended to grow. At the same time, the share of the value added of farms was constantly decreasing from 40 to almost 20 percent, and retailers accounted for the main share. The study Sanders et al. [2] revealed the features of the organic food farms and organic food chains in distribution of the value added in EU Countries. The main conclusions are that manufacturers themselves rarely get more than $40 \%$ of the value added of the final product. The rest is distributed between processors, wholesale and retail sectors.

Delautre [3] reviewed the process of the value added distribution in the information and communications technology (ICT) in manufacturing sector. She focused on the evolution of the distribution of the value added across firms and across countries, namely, the movement of the essential share of the value added to China, in favor of local producers, even for branded products. Kazekami [4] explore process of creating added value in Japan. VelezPareja [5] and Biddle et al. [6] focused attention on the concept "Economic Value Added" (EVA). It takes away the study from the essence of this phenomenon, shifts attention to the search for tools of increasing revenues and profits. In this form, the problem of the value added becomes a section of marketing and strategic management. The main issue here is "how to create" value added, while for the purposes of this study the answer to another question "how is it distributed" is of greater interest. However, almost all studies paid attention to distribution of the value added between firms and group of market agents or countries. In-firm distribution of the value added is not in the center of attention of the researchers. Appropriate techniques that allow external assessment and measurement of infirm value added are not presented in Pletnev [7, 8, 9].

Other direction of the investigation developed in this research is the study of the distribution process of the surplus value. Starting with the works by A. Smith, D. Ricardo, 
and K. Marx [10] profit, land rent and taxes are in the structure of the surplus value (nominally it is value added minus wage). The assertion that surplus value is the result of exploitation of worker goes through the works by Marx like a red line. A large share of the surplus value in total revenue points at more unfair distribution system. Within the framework of the development of Marxist political economy, the process of creating surplus value, the contradictions in the process of its distribution and the labor nature of value (Roemer [11], Moseley [12], Krishnamurti et al. [13], Marginson [14], Veneziani [15]) are investigated. Special attention should be paid to the work Dzarasov [16], which indicate the existing disproportions in the distribution of the value added between the subjects of the world economy and corporations. This direction in the analysis of created (surplus or added) value still has not lost its relevance and inspires many new studies Tomba [17], Fine and Saad-Filho [18], Bassanini and Manfredi [19]. The common drawback of the reviewed works is their theoretical and abstract character, formulated hypotheses and assumptions are not confirmed on the concrete data of specific companies, and techniques for estimating value added distribution are not developed.

\section{Methodology and Data}

The article considers in detail the distribution of the value added to Gazprom according to the consolidated financial statements for 2012-2017, reveals trends and patterns that allow to determine the strengths and weaknesses of this corporation as a driver of the development of the Russian economy. The main stakeholders (state, employees, top management, owners, and other investors) are identified. The research uses methods of synthesizing the partial indicators of various forms of reporting, methods of regression analysis, data from Gazprom's official website and open sources. The uniqueness of the research consists in the author's method of calculating the amounts of the value added received by each stakeholder.

Based on definition of value added as a newly created value, it can be calculated, as a difference in revenue and incurred material expenses. On the other hand, value added can be defined as the sum of payments to the stakeholders who get a piece of the "pie". The second approach allows not only to assess the dynamics of the value added, but also to consider its structure in detail. All calculations and analysis are performed in accordance with the consolidated financial statements of Gazprom, prepared in accordance with IFRS (Gazprom. Reports 2017. IFRS consolidated financial statements [online] < http://www.gazprom.com/f/posts/12/255042/gazprom-ifrs-2017-12m-en.pdf $>$ Accessed 05.08.2018) and the quarterly report of the issuer for the 1st quarter of the next year (Gazprom. Reports 2018. 1Q 2018 Quarterly report [online] $<$ http://www.gazprom.ru/f/posts/01/851439/gazprom-emitent-report-1q-2018.pdf>

Accessed 05.08.2018). Estimation of the elements of the value added distributed to various entities is carried out using the following data: net profit, from the statement of total income in the consolidated financial statements under IFRS (share of owners), labor costs, from Note 26 to the consolidated financial statements under IFRS (share of employees), remuneration to the members of the board of directors and the members of the management board, from item 5.3 of the quarterly report of the issuer (share of managers), paid taxes, including the taxes paid by employees, from Note 30 to the consolidated financial statements under IFRS (share of the state), interest paid from Note 27 to the consolidated statements under IFRS (share of investors). In addition, the data on paid dividends of PJSC Gazprom from the official site is used (Gazprom. Dividends. [online] $<$ http://www.gazprom.com/investors/dividends/>, Accessed 05.08.2018). 


\section{Results}

The gross value added of Gazprom has a stable positive dynamics, for the whole period it has increased by 5 times and amounted to 3,894.9 billion rubles in 2017 or $60.9 \%$ of sales revenue. The dynamics of the value added was not stable - by the end of 2014 , its absolute value decreased by more than 1 trillion rubles, at the same time there was a sharp decline of the share of the value added in revenue up to $50 \%$. It was connected with external, political factors (the first wave of sanctions, a reduction in the cost of oil and the ruble exchange rate), which led to a deterioration of the business environment for Gazprom. However, in 2015, the company almost returned to the value added indicators of 2013, and by 2017 reached the absolute maximum of this indicator.

The high value added share is explained by the nature of Gazprom's production activities: since it is a mining company, the value added is created by the very fact of production (extraction) and sale of the extracted raw materials - natural gas. At the same time, there are reserves for increasing the value added share: Gazprom has not yet been admitted to the realization of its product at retail on foreign markets. There is also a potential for the value added growth in the sphere of deep processing of natural gas. The construction of new gas pipelines Blue Stream and Nord Stream 2 is expected to be completed. The value added share in the proceeds from the sale of Gazprom for the considered period has steadily decreased from a maximum of 87.2 in 2006 to $60.9 \%$ in 2017 (Fig. 1). An especially sharp decline is observed in 2013-14. For Gazprom itself, a decrease in the value added share should become an alarm signal - this means that the place of the corporation in the value added chain becomes more vulnerable, and the corporation itself receives less of a significant part of the income.

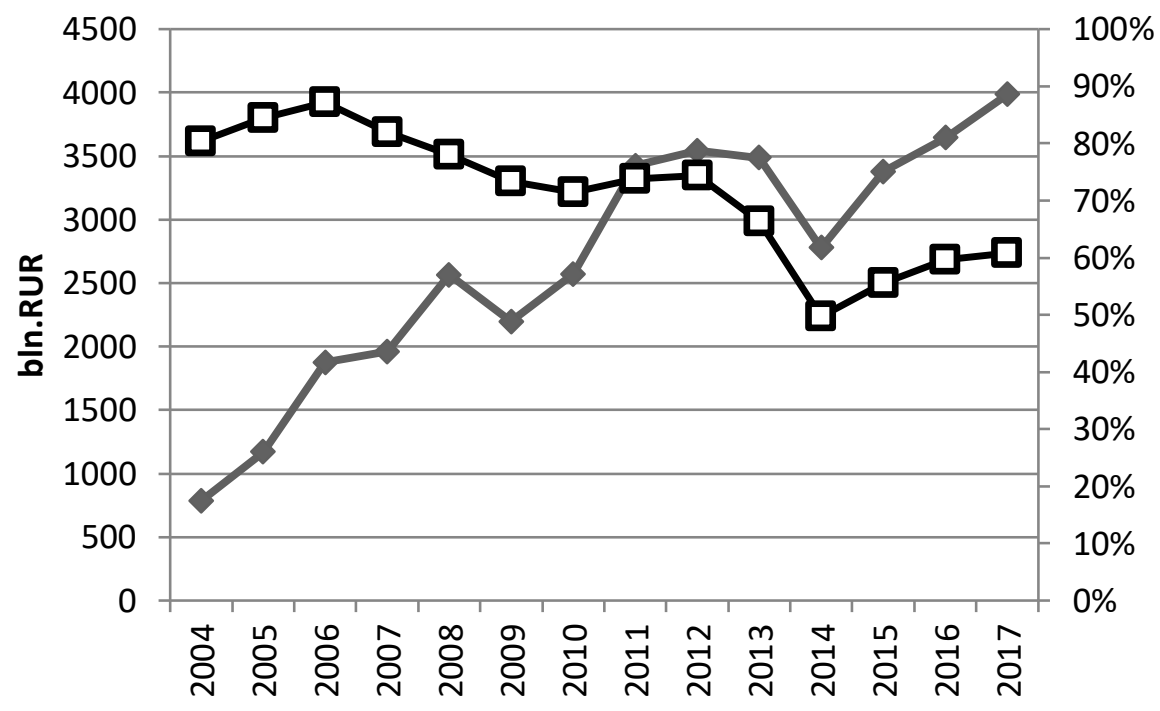

$\leadsto$ Value Added, bln.RUR $\quad \square$-Value Added Share in Total Revenue

Fig. 1. Dynamics of value added of Gazprom corporation, 2004-2017

The detailed analysis of the value added structure shows that different stakeholders of the corporation (owners, the state, employees, managers, investors) receive a significantly different part of this value added. This indicates disproportions in the structure of relations in the corporation, and the absence of a single vector of structural change shows the effect on the corporation of a multitude of differently directed forces. The following distribution 
of the value added from Gazprom was revealed in 2004-17 (see Fig. 2)

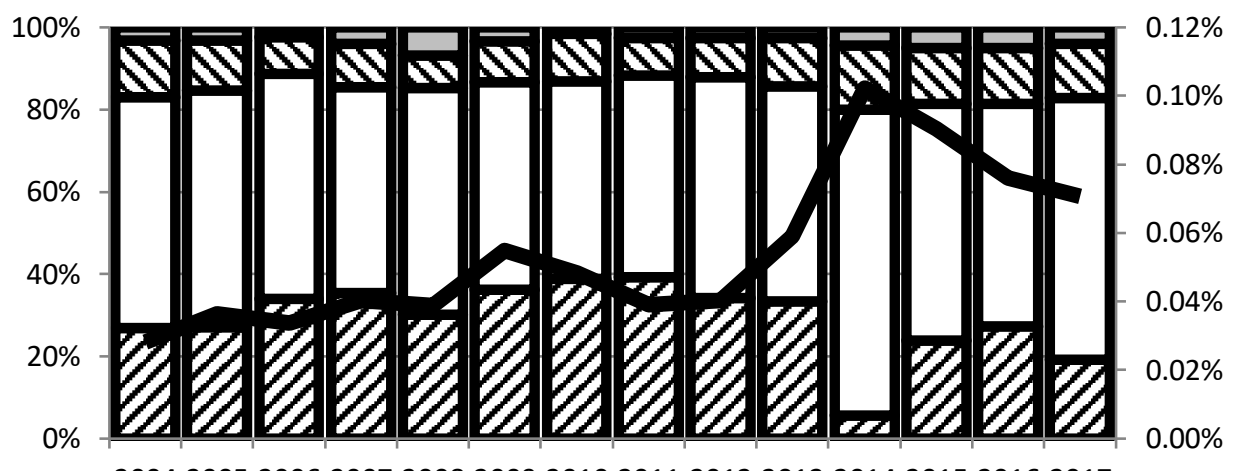

20042005200620072008200920102011201220132014201520162017

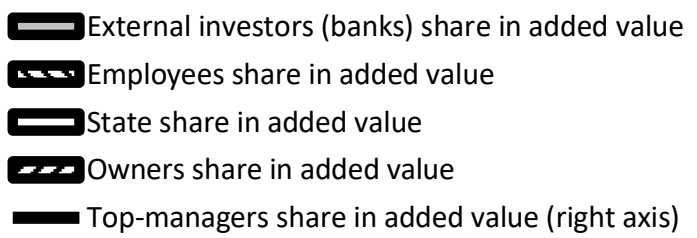

Fig. 2. Distribution of value added of Gazprom corporation, 2004-2017

The main share of the value added in general state-owned Gazprom corporation is appropriated by the state through the tax and customs system (the share fluctuates around $50 \%$ of the total value added), as well as through insurance premiums to the social insurance system. This is mainly due to the customs payments, mineral extraction tax and value-added tax (up to $2 / 3$ of the total amount of taxes and customs payments). In absolute terms, the state received from "Gazprom" 20.80 trillion rubles, $37.3 \%$ of its total revenue or $55.7 \%$ of its value added for 2004-2017. In that sense, Gazprom can be named as "National treasure" ("natsional'noye dostoyaniye" in Russian, it is motto of Gazprom). In absolute terms, both the total amount of taxes and the amount of the specific tax types are steadily growing, the basic growth rate (2017 to 2003) is 5.75, which corresponds to approximately $14.4 \%$ of the average annual growth. At the same time, revenue grew by $15.7 \%$ on average over the year. Therefore, in relative terms, the state's share is insignificantly declining. The year 2014 brought some changes and the consequenced remission. During this period, the state's share increased (in absolute terms, growth was also observed).

The dynamics of the tax burden structure of Gazprom corporation can be seen in Figure 3. As we can see from the figure, the state receives the main share of the value added through indirect taxation, so, in fact, these taxes are paid by consumers. We are talking about customs payments; value added tax and excises (up to $35 \%$ of the value added, up to $70 \%$ of the total tax burden). Also, a significant part is the mineral extraction tax - a peculiar form of appropriation of land rent. In the figure it is "hidden" in "other taxes", making $18 \%$ of all value added. Also, the share of taxes paid "for employees" is insignificant - we are talking about the personal income tax and payments of social contributions (this part is close to $5 \%$ of the value added by 2017). The profit tax in the total amount of the value added does not take a significant share (in $2017-5.7 \%$ ). 


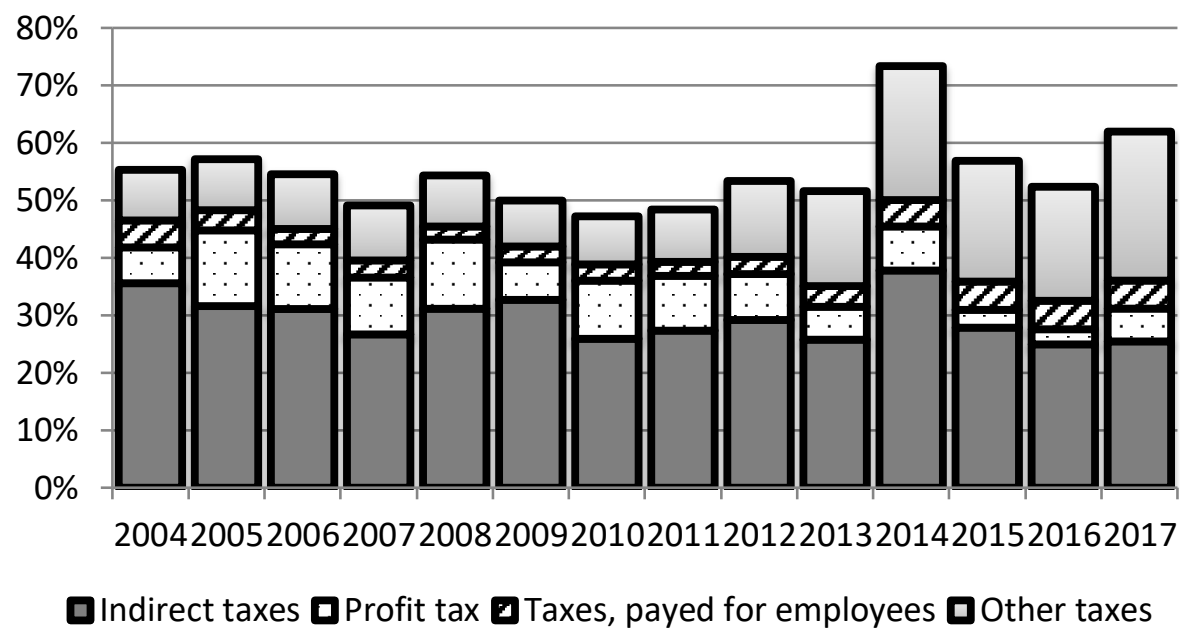

Fig. 3. Structure in dynamics of State share in value added of Gazprom corporation, 2004-2017

The second most important value added recipient are the owners of the corporation, among which the state occupies the central place. For the whole period under review, two trends can be singled out: a steady increase in the share of owners in 2004-2011 and a steady decline (in 2012 -17). At the same time, we should note a slight increase in the value added share consumed by the owners. In absolute terms, the amount of dividend payments increased by 5 times - from 28.2 to 141.8 billion rubles. In addition, since 2013, a longterm "rule" has been violated - a decrease in the share of net profit in the structure of the value added was accompanied by a decrease in the share of dividends. In 2013, the share of owners decreased by 0.8 percentage points, and at the same time the share of dividends increased by 0.9 percentage points, or almost by $20 \%$. In 2014, almost all net profit was paid in the form of dividends (see fig.4).

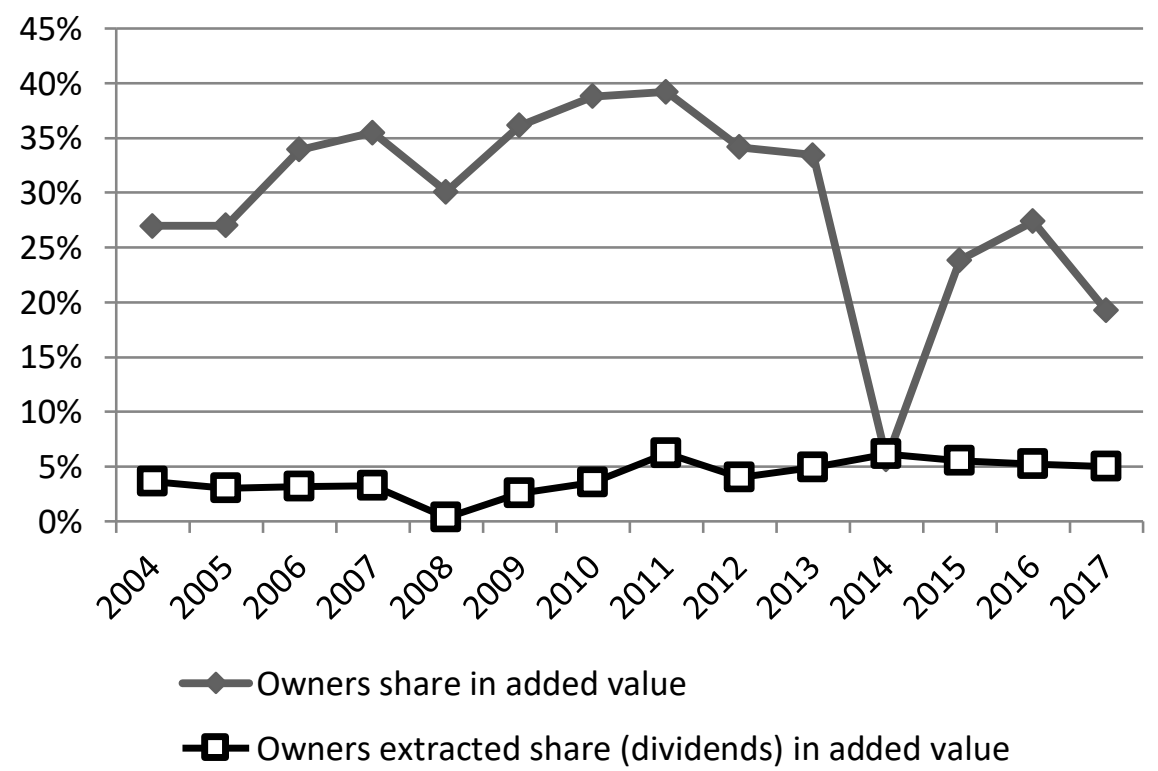

Fig.4. Dynamics of owners share in value added of Gazprom corporation, 2004-2017 
In addition, it should be noted that accounting for the share received by the state as the owner of Gazprom (50\%), allows to adjust the given above assessment of the value added share appropriated by the state. Together, taxes, customs payments and corporate profits allow the state to appropriate up to $70 \%$ of the total value added and this share is almost invariable.

The third most important subject in terms of the value added appropriation are the employees of the corporation. Their share was steadily declining in the period from 2004 $(13.8 \%)$ to $2011(9.1 \%)$. After that there was a change in the trend. Today about $13 \%$ of the total value added is the share of employees (it should be noted that the average salary of Gazprom employees is significantly higher (more than 3.5 times) than the national average (121,000 rubles per month). At the same time, the share of managers is steadily increasing from $0.028 \%$ (in 2004) to $0.071 \%$ in 2017 (Figure 5). It is worth noting that after 2014 a new trend appeared - reducing both the share of managers in the value added, and the absolute income received by the top management of the corporation. The observed increase in average wages is a consequence of both the reduction in the number of employees and the growth in the value added in absolute terms. The detected increase in the share of employees in the gross value added of Gazprom in recent years indicates a partial removal of the alienation of employees from the corporation.

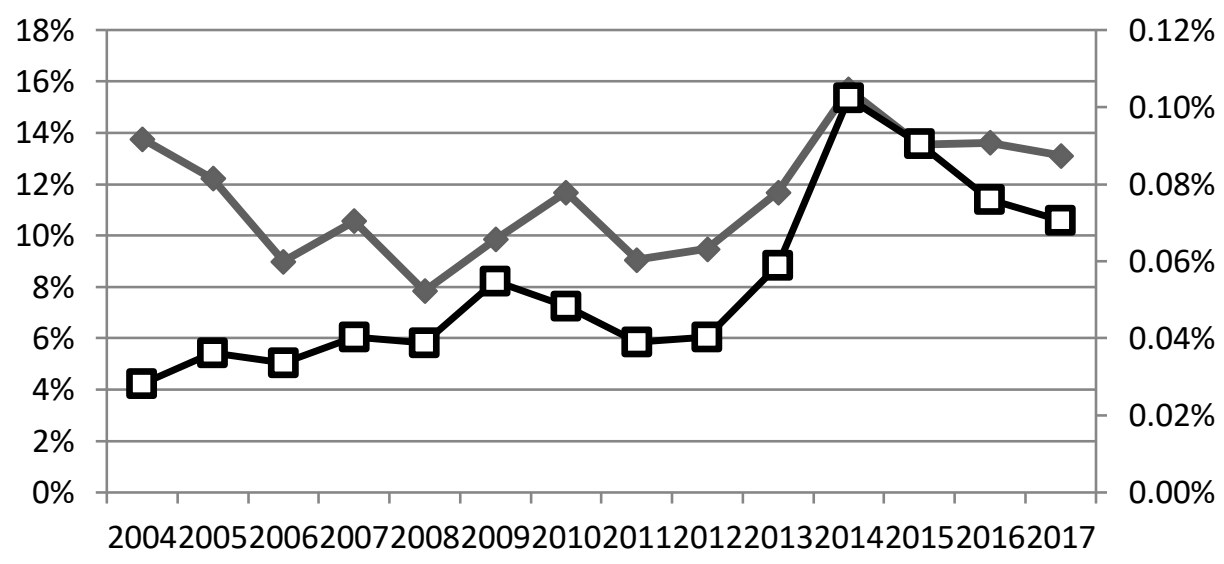

$\sim$ Employees share in added value

- Top-managers share in added value (right axis)

Fig. 5. Dynamics of employees share in value added of Gazprom corporation, 2004-2017

\section{Conclusion}

The distribution of the value added of the largest Russian corporation Gazprom reflects the system of power in it. The stable share of the state as the largest owner and strong economic agent of about $70 \%$ shows that the corporation operates, first of all, for the benefit and in the interests of the state. However, this conclusion is purely economic. The subsoil in Russia belongs to all the people. Disposition of income generated by the company based on the use of mineral resources and should be directed to the needs of the people. This happens through the state's performance of its functions due to revenues received through taxes from Gazprom. The second important participant in the distribution of value added is Gazprom employees. They receive $10-15 \%$ of the added value, which is quite a lot for a modern high-tech company. The proportion of employees is gradually 
increasing, which indicates an increase in the influence of workers on the corporation. The share of the owners of the company (shareholders) is stable, they receive about $5 \%$ in the form of dividends. The rest of the subjects (banks, top management, sponsored projects (including in sports)) do not receive a significant share of Gazprom's added value. Further research can be aimed at the detailed structuring of individual directions of the distribution of value added and the assessment of power in the corporation based on the study of longterm trends in the distribution of its value added.

\section{References}

1. D. Coltrain, D. Barton, and, M. Boland, International Journal of Scientific and Technology Research, 1(9), 42-45 (2000).

2. J. Sanders, D. Gambelli et al., Distribution of the added value of the organic food chain. (Braunschweig, Thünen Institute of Farm Economics, 2016)

3. G. Delautre, Research Department Working paper, 16, (Geneva: International Labour Office, 2017).

4. S. Kazekami, Eurasian Economic Review, 7, 389-410 (2017).

5. I. Velez-Pareja, Cuadernos de Administración, 22, pp. 7-31 (2001).

6. G. Biddle, R.M. Bowen, J.C. Wallace, Journal of Applied Corporate Finance, 12(2), 69-79 (1999).

7. V. Barhatov, D. Pletnev, E. Nikolaeva, Procedia-Social and Behavioral Sciences, 124, 521-527 (2014). DOI: 10.1016/j.sbspro.2014.02.515

8. E. Nikolaeva, D. Pletnev, Journal of Advanced Research in Law and Economics, 6(4), 768-774 (2015).

9. D. Pletnev, Procedia - Social and Behavioral Sciences, 238, 388-397 (2018).

10. K. Marx, Theories of Surplus Value, (London: Lawrence \& Wish Art, 1951)

11. J. Roemer, A General Theory of Exploitation and Class, (Cambridge, Mass., Harvard University Press, 1982)

12. F. Moseley, American Economic Review, 78 (1), 298-303 (1988).

13. P. Krishnamurthy, S. Deenadayalan, P. Srilatha, International Conference on Entrepreneurship and New Venture Creation: International Models and Benchmarks Proceedings, 12 (2011).

14. S. Marginson, Cambridge Journal of Economics, 22(5), 573-585 (1998).

15. R. Veneziani, Journal of Economic Theory, 132, 189-207 (2007).

16. R. Dzarasov. Debatte, 19(3), 585-597 (2011).

17. M. Tomba, The Commoner, 12, 23-37 (2007)

18. B. Fine, A. Saad-Filho, Review of Political Economy 30(3), 339-354 (2018).

19. A. Bassanini, T. Manfredi, Eurasian Business Review. 4, 3-30 (2014). 